\title{
Refining Tax Accounting Education to Improve Accounting Students Skills and Competences
}

\author{
Evelyne Brilliana Susanto ${ }^{1,}$ Ria Sandra Alimbudiono ${ }^{2 *}$
}

\author{
${ }^{1}$ University of Surabaya, Surabaya, Indonesia \\ ${ }^{2}$ University of Surabaya, Surabaya, Indonesia \\ *Corresponding author. Email: ria_us3150@yahoo.com
}

\begin{abstract}
This study aims to explore the refining way in tax accounting education to improve the students skills and competences. It is applied research, focusing on some applied recommendations; Data was collected through interviews with students and lecturers, observations, and document analysis with 13 participants. Participants are also invited to do some tax cases. Findings show that tax accounting education plays a significant role in students basic taxation knowledge, skills, and competences. This is very fruitful to prepare them when they want to have a career in the taxation field. However, they were not very skilled in doing complex tax cases in the real condition. This study is beneficial for accounting educators to refine the curriculum and tax accountants to identify further taxation skills and competences needed for young accountants. This study tries to evaluate the broad skills and competences of students. Further studies can be expanded to more detailed skills and competences so that users can improve the tax accounting syllabus.
\end{abstract}

Keywords: tax accounting, learning system, skills, competences.

\section{INTRODUCTION}

Tax is a primary source of a country's income (Wafroturrohmah and Suyatmini 2013). The govern-ment will allocate the income tax to finance infrastructure, education, telecommunication, and many other things to develop a country (Asonitou and Hassall 2019). Therefore, the paradigm that paying tax is an obligation should be changed since paying tax is also a right to finance and invest in the country (Nathania and Davianti 2018).

Tax awareness must be built from an early age. The awareness that taxes are the rights and obligations of citizens is shown by compliance with tax regulations. Compliance is triggered by a good understanding of what must be deposited, collected, withheld, and reported. This understanding can be obtained with for-mal education, namely tax accounting education. High demand for tax practitioners triggers educational institutions to prepare their graduates (Hayes et al. 2018). At University "XYZ", learning taxation starts with tax law, taxation, and then tax planning subjects. Each subject teaches various tax regulations with different levels of depth.

However, based on the interview and evaluation of students skills and competences, it was found that $50 \%$ of students who passed the taxation subjects had not been able to state the tax rate correctly. In addition, some of them cannot fill in the annual corporate tax form. Therefore, improvement must be made. This study aims to explore the improvement of tax accounting education to increase the skills and competences of accounting students in University "XYZ". 
This study is applied research. Therefore, it focuses on recommendations that the accounting department can use to improve the tax accounting learning pro-cess. The benefit of this study for lecturers is to im-prove their learning process, so the student is ready for a career as a tax accountant in the future. It is also beneficial for accounting users, such as tax consulting firms, businesses, and government, to understand and be part of the improvement.

This study is divided into several sections. Section 1 describes the background, objective, and purposes of the study. Section 2 starts with a literature review regarding tax accounting education. Section 3 presents the research methodology, followed by section 4 , which presents findings and all discussions and recommendations. The conclusions are set out in Section 5.

Tax accounting is an accounting field related to taxation, which refers to regulations, laws, and rules (Hayes et al. 2018). It is applied in accordance with tax regulations and should be in line with commercial accounting, which complies with international finan-cial reporting standards (Carvalho \& Salotti 2013, Runtuwarow \&Elim 2016).

According to the International Federation of Accountants (IFAC), globalization pushes accountants to have excellent skills and competences, teamwork, leadership, problem-solving ability, and analyzing skills (Rebele \& St. Pierre 2019). Critical thinking and intellectual skills enable a professional accountant to solve problems, prepare judgments and decisions in complex organizational situations (Asonitou \& Hassall 2019). These competences do not develop quickly over a short period (Papageorgiou \& Callaghan 2020, Rebele \& St. Pierre 2019). However, previous studies reveal that the top technical skills required for freshgraduate students are financial statement preparation and taxation skills (Asonitou \& Hassall 2019, Daff et al. 2012). Understanding tax principles is desirable, but tax planning is not necessarily desired (Hayes et al. 2018).

Taxonomy is categorizing things based on specific characteristics, wherein in the education field, taxon-omy is used for categorizing learning objectives. The taxonomy is classified into three domains: cognitive, affective, and psychomotor. Bloom's Taxonomy has been used for more than fifty years as the basis for educational objectives. The cognitive domain of Bloom's Taxonomy classified behavior into six categories: C1 (knowledge), C2 (comprehension), C3 (application), C4 (analysis), C5 (synthesis), and C6 (evaluation) (Gunawan and Palupi 2012).

\section{RESEARCH METHODS}

This study is exploratory qualitative research. It is applied research since it tries to recommend problem solving in an accounting department in Malang, Indonesia. The subject is batch 2017 accounting students in University "XYZ", with a GPA $\geq$ of 2.5. There were 134 students, and participants were determined by $10 \%$. The participants were selected randomly. The scope of the taxation knowledge was about Article 21 Income Tax, Individual Annual Tax, Article 23 Income Tax, and Value Added Tax.

The methods used to collect data were interview, observation, and document analysis. All the methods were done online due to the Covid-19 pandemic. The steps of this study were selecting participants, asking them to do some small tax cases, joining the taxation class to observe students' activities in class, and then interviewing the participants and lecturers. The tax cases were made based on the materials that have been taught in Semester 4 to Semester 6 that cover Article 21 Income Taxes, Article 23 Income Taxes, Value Added Tax, and fill in Individual Annual Tax. The tax case results were then analyzed. A triangulation test was done to improve the validity and reliability of the data.

\section{RESULTS AND DISCUSSIONS}

Based on observation and interview with lecturers, taxation knowledge has been de- 
livered in class and covered all basic taxation knowledge, starting from tax law to the calculation and problem solving on many tax cases. Lecturer " $" \ddot{"} "$ said that students learn about counting individual income taxes, corporate income taxes, value-added tax, and fill in reports re-quired by the government. They also add topics that have been learned in the Brevet program. These topics are delivered in some subjects: Tax Law, Taxation, and Tax Planning, which cover Level 1-3, Level 4, Level 5, and Level 6 of Bloom's Taxonomy, respectively.

Table 1 Students' Score in Tax Subjects, GPA, and Quiz.

\begin{tabular}{crrrrr}
\hline Name & Tax Law & Taxation & $\begin{array}{c}\text { Tax Plan- } \\
\text { ning }\end{array}$ & Quiz & GPA \\
\hline PPL & 94.6 & 87.6 & 87.8 & 91 & 3.92 \\
LBC & 88.8 & 95.6 & 90.8 & 95 & 3.90 \\
LR & 96.2 & 79.8 & 90.0 & 83 & 3.87 \\
MF & 90.6 & 78.0 & 88.6 & 76 & 3.85 \\
EGS & 96.2 & 87.0 & 85.6 & 76 & 3.79 \\
SK & 90.4 & 80.0 & 94.4 & 34 & 3.76 \\
MS & 90.4 & 78.6 & 86.6 & 53 & 3.61 \\
GTT & 84.4 & 75.4 & 85.8 & 56 & 3.52 \\
SPS & 81.4 & 83.0 & 81.6 & 42 & 3.51 \\
F & 80.6 & 73.6 & 84.8 & 31 & 3.50 \\
GTR & 62.8 & 61.2 & 60.4 & 43 & 2.93 \\
AP & 78.8 & 63.0 & 70.6 & 48 & 2.84 \\
IFE & 81.2 & 75.8 & 66.6 & 25 & 2.70 \\
\hline
\end{tabular}

Participants taxation skills and competences can be seen from their score on the various subjects related to tax. Besides, participants should do a quiz about tax cases and the quiz score will be compared with the score they obtained after taking tax subjects. Table 1 shows that many of the participants achieve good scores in tax law subjects. However, it is declining in taxation subject and some of them get improvement in tax planning subject. This finding reflects that the higher level of Bloom's Taxonomy serves the higher level of difficulty in understanding the topics.

Data analysis in detail shows that there are similarities in the test result between those 13 participants, which are lack in mastering the VAT terms, lack in classifying activities into the Individual Annual Tax, lack in detail while filling the Individual Annual
Tax, and lack in memorizing rate and allowance terms. However, some participants, namely F, SK, SPS, GTR, APE, and IFE, lack in mastering Article 21 Income Taxes, where Article 21 income tax is basic and common knowledge in taxation. Besides, F, GTT, SK, and SPS lack the Article 23 income taxes rate. Considering the quiz results, it can be concluded that the participants face declining taxation skills, competences, and knowledge due to the unawareness to review and repractice the tax materials after taking the subjects. The participants obtained a good score is due to reviewing tax materials within one year. According to Hayes et al. (2018), technical skills are significantly desirable for undergraduate students. It also includes taxation subject, where fill-in Individual Annual Tax is one of the technical skills.

Besides technical skills, problem-solving and analyzing skills are also important as a requirement for an accounting graduate (Asonitou \& Hassall 2019). MS had a passable ability to solve problems because MS could solve the tax cases (Article 21 and Article 23 Income Taxes, and VAT) and prepared a tax planning program. PPL has a good problem-solving ability because PPL was able to answer the third question nearly perfectly. So as the ability, PPL had a proper knowledge of competence due to the ability in answering the basic calculation well that resulted in better competences. However, as with other participants, PPL was lacking in classifying the components of Individual Annual Tax, especially in the first attachment, resulting in different results.

Regarding the analyzing skills, PPL had a proper skill in analyzing the classification of each attachment in Individual Annual Tax. As for the overall questions, PPL had good technical skills in tax since PPL could answer the entire cases nearly perfectly. This is also supported by Daff et al. (2012) regarding the same line between GPA and competences. Besides, based on Table 1, it can be seen that PPL had increasing taxation skills and competences from the first subject to the next subject she learned. 
Meanwhile, AP had the second-lowest GPA, but she forced herself to answer the Individual Annual Tax. AP still had a lack of good technical taxation skills even though AP able to fill the Annual Tax. AP could answer 2 cases correctly out of 3 of Article 23 Income Taxes cases because AP did not remember the rate. AP was also able to answer 4 cases right out of 10 VAT cases because AP did not understand the VAT terms about which tax base rate should be applied and what if there is a return. Based on Table 1, AP faced declining taxation skills and competences from the first subject to the next.

Even some participants face many difficulties in the taxation subject; some of them choose taxation as their major in an undergraduate program. Their consideration is because as a developing country, Indonesia is developing the taxation system; thus, job opportunity is widely opened. Corporations are hiring an accountant who is good in the financial report and the taxation field (Nathania \& Davianti 2018).

After interviewing and observing the skills and competences of the participants, this study also obtained data regarding the difficulties during the learning process. In an undergraduate program, subjects related to tax are divided into four subjects, with one subject per semester. Based on Bloom's Taxonomy theory, the first tax subject is tax law covering Level 1 until Level 3. According to the lecturer (Mr. Ax), in the tax law subject, students are taught about the regulations; thus, students will have the basic taxation knowledge and understand tax purposes. Furthermore, the second tax subject is taxation, covering level 4 (analysis), where students need to analyze which rate or regulations should be used.

Moreover, the taxation accounting subject covers level 5 (synthesis). In the subject, students need to com-bine the elements of tax and accounting to journalize tax transactions. At the last level, the tax planning and application subject covers Level 6 (evaluation) due to the needed ability to define better corporate tax strategy.
Seeing Table 1, the first ten participants obtain an excellent score in tax law subject while two got a very good score and one got a passably score. These indicate that the participants were primarily able to follow the class and understand the materials very well, while few of them were unable. However, eleven out of thirteen participants face a declining score in taxation subject. Comparing with the quiz score, eleven respondents are facing declining taxation skills and competences recently.

LBC, one of the participants, felt that the four-class meetings in filling the Annual Tax form were enough to give a basic understanding. Even though LBC admitted that the number of meetings was enough, LBC found difficulty as the filling form exercise was still done conventionally, while the electronic form is now being used in real reporting. However, in Article 21 Income Taxes material, LBC argued that there was no lack in the learning process because the basic calculations taught were excellent, enhanced by the extra practice time in assistant classes. For Article 23 In-come Taxes, LBC felt that she is capable enough to understand. However, LBC argued that students sometimes got non updated material. When confirming the lecturer, Mr. Ax stated that if the government changes the regulation, students will feel that their materials are not updated. This is a classic problem and students must update themselves. Meanwhile, for valueadded tax materials, LBC thought that the learning process is not deep enough due to the lack of cases variation done in the class, for example: in calculating value-added tax, as well as a less detailed explanation regarding transactions that can be categorized as output and input value-added tax. LBC contended that the VAT transaction is confusing. In fact, other respondents mentioned the same with LBC.

EGS understood the taxation materials, even though EGS obtained 87 scores (A) in the taxation subject. It can be seen from the quiz. EGS argued that filling the Annual Tax form was helpful and explained clearly due to the existence of four class meetings; be- 
sides, the lecturer was able to teach well. However, the class condition was sometimes less conducive, either in taxation class or other classes, due to many students in a class. According to a lecturer (Ma'am Kn), there were around 70 students in a class with probably three parallel classes. The uncomfortable conditions often make lecturers tired of reprimanding students, resulting in difficulties in creating calm learning conditions. This makes students who want to be serious to learn are quite disturbed by filling the Annual Tax form material, which requires high concentration each week. Responding to that, the lecturer (Mr. Ax) also commented that each student has the ability and limits in learning, where those who still able to pay attention to lecturers will keep the situation calm.

To deal with the difficulties, this study concluded in various recommendations. Tax Law is the first tax subject taught in the university covering the first three level of competences; thus, students are still unfamiliar with the terms where the difficulties lie on the students' ability to memorize regulations and lack in understanding the meaning of regulation as interpreting it. Meanwhile, the level of achievement for students to get a good score is incredibly high; thus, the learning process has already been done well. However, since the incapable students still felt some difficulties, they should intensely make an interactive class to discuss the laws and regulations. It is important because the entire students have their interpretation of laws. Thus, lecturers need to provide a discussion, and if it is necessary, provide a mini quiz after the class by using Quizizz. This can make students feel free and more interested to discuss the tax law. This recommendation is the best way to cover the current condition for both sides since the capability of students is very varied, and discussion should be the primary learning method. Thus, the recommendation is "Increasing number of discussions".

Taxation is the second subject covering level 4 in analyzing the calculation. It is harder than tax law subject; thus, the diffi- culties are varied. Participant PPL argued that time limitation makes the explanation become more theoretical and explained in a big line; thus, the materials are better to be published three to four days before class as it can help students prepare and have a general description of the case. This can minimize the theoretical explanation in class, and lecturers can focus more on providing questions and exercises. This method also motivates students to learn independently. The meeting is more about discussion class. By providing the materials before class, students are expected to prepare main points to ask the lecturers as well. By making a discussion room in a class, students will be encouraged to be more interactive. This recommendation is the best way to cover the current condition about time limitation in class for both. Thus, the recommendation is "Publishing materials before class".

As still for the taxation subject, the participants stated that there is a lack of lecturer lectures in class, lack of intensive in the teaching materials, and favoring students to keep continue study at home. It is known that the taxation subject is in $\mathrm{C} 4 \mathrm{n} \mathrm{C5}$ of taxonomy. So, it is better if the lecturers give assignments and ask students to self-study. By giving homework, students will be more motivated to study and discuss with friends, and they can have more practice. The assignment can also cover the lack of example variations since this is important for students to illustrate what will exist in real life. At the meeting, lecturers provide feedback, so students can correct their mistakes. This recommendation is the best way to cover the current condition for both sides since the incapable students cannot study independently; thus, homework can force them to discuss with friends. Thus, the recommendation is "Providing homework regularly".

Still, in the Taxation subject, the entire participants argued that they tend to forget the materials studied earlier and lack awareness in reviewing or re-practice. Meanwhile, the lecturer stated that there would be a review at Week 14. However, it is better if the reviewing method is changed. Students can 
be more interested in reviewing the tax materials by doing games. The games aim to improve the interest in studying. One group consists of four to five students. Students in each group should answer the questions as fast as they can. Thus, every student will get the same chance of answering it. The point is +4 (correct answer), -2 (wrong answer), and -1 (empty answer). The score they got will influence the final score of the taxation subject. This can be done to improve students' willingness to review tax materials. The game will be done for two hours, and the last hour will be a focus on reviewing materials that students might still not understand. This recommendation is the best way to cover the current condition. Thus, the recommendation is "Doing learning methods by game".

The participants also argued that there is a lack of tax facilities such as tax seminars or inviting tax officers from tax institutes, and the regulations are less updated. Participant LBC stated that the regulations or rates they read from the book are not updated. To deal with this, a tax community should be established. This community aims to help students and lecturers support the lecturing system; for example, the tax application consists of the newest tax regulations. Besides, the tax community can be the intermediary between students and the business. In this community, the activities will be about tax activities, for example, holding a seminar from the senior practitioner or authorized officer from government and internship program at a tax consultant firm. By having this community, students can be more facilitated to discuss tax news, the updating regulation, and other tax discussions. This can improve students' interest, so students can be more aware of the importance of tax and review the tax materials after taking the subject. This recommendation is the best way to cover the current condition for both sides since students are not yet facilitated to deepen their interest in tax, and lecturers should consider this community in concern. Thus, this recommendation is "Providing tax center".
Participant LR remarks last difficulties for the Taxation subject. Participant LR argued that they were not taught to complete Annual Tax electronically (E-SPT) since the filling is just on papers. The participants stated that they want to learn how to fill ESPT. Basically, E-SPT has a similar function as paper, but it provides more automatic functions. For educational purposes, it is still better to educate students filling the Annual Tax manually because it forces students to be more careful and know to report tax correctly. Learning manually is more functional and easier for students to be carried every week. However, the lecturer can still provide a tutor about filling the E-SPT by sharing the video so that students can have a broader insight of E-SPT. Thus, the best recommendation is "Giving a tutor video".

The last tax subject is Tax Planning. This subject covers the last level of Bloom's Taxonomy, meaning it has the highest level of learning, named evaluation. According to participant EGS, students were asked to summarize the topic that a group presents, then a Question-and-Answer section, and at last, the lecturer explained the material. Meanwhile, the remaining participants argued that they sometimes lack in mastering the tax concept and interpreting the case even though they have already given various practices. Based on the level, this subject should give a broad insight to students about how to evaluate a complex case in the business. So, the learning system should be refined. The lecturer can give an integrated tax planning and reporting in a company; then, students will try to evaluate whether the company has done proper tax planning and reporting or not. It can be in article 21 , article 23 , or corporate taxation system or individual taxation system. Students will accept the integrated case three or four days before the meeting. Then, students try to analyze and evaluate at home, prepare the presentation. Next, it continues to a Question and Answers session. At last, the lecturer will give a summary. Thus, the recommendation is "Refining the learning system". 


\section{CONCLUSION}

Tax accounting education plays such a significant role in the students' taxation knowledge, skills, and competencies. In general, students have good skills and competences after joining four subjects related to tax. Even though education increases the students' skills and competencies, there are some difficulties while learning it. The lack of inability to memorize regulations and articles and lack of understanding of the meaning of regulations and interpret it resulted in students incapability in following the materials. Besides, the difficulties also cover on the more theoretical explanation due to time limitation, lack in giving examples includes variations, no E-SPT, students tend to forget the materials directly after taking it and lack of awareness to review, lack in tax facility, and lack of understanding the tax concept as well as interpreting the meaning of the case.

Thus, to deal with these difficulties, this study in-cludes some recommendations: an increasing number of discussions in class and providing mini quiz as well as discussing the answers thus students can know the correct answer, publishing materials before entering class to let students prepare themselves, providing homework regularly to give students more practice, providing a video about E-SPT to let stu-dents aware about it, providing games at class in or-der to adapt with the digital era, providing tax center to facilitate those who like tax, and reversing the learning system by doing summary after the class ends with either submitted it next week or next few hours.

This study is very fruitful in giving insights about the skills and competencies of the students and refinement can be done for this subject. This study tries to evaluate the broad skills and competencies of students. Further studies can be expanded to detail skills and competences, so users can get a clear way to im-prove the tax accounting syllabus.

\section{REFERENCES}

Asonitou, S. \& Hassall, T. 2019. Which skills and competences to develop in accountants in a country in crisis?. The International Journal of Management Education 17(3): 100-308.

Carvalho, L.N. \& Salotti, B.M. 2013. Adoption of IFRS in Brazil and the Consequences to Accounting Education. Issues in Accounting Education 28(2): 235-242.

Daff, L. Lange, P.D. \& Jackling, B. 2012. A Comparison of Generic Skills and Emotional Intelligence in Accounting Education. Issues in Accounting Education 27(3): 627-645.

Gunawan, I. \& Palupi, A.R. 2012. Taksonomi Bloom - Revisi Ranah Kognitif: Kerangka Landasan Untuk Pembelajaran, Pengajaran dan Penilaian. Jurnal Pendidikan Dasar dan Pembelajaran 2(2): 98-117.

Hayes, S. Freudenberg, B. \& Delaney, D. 2018. Role Of Tax Knowledge And Skills: What Are The Graduate Skills Required by Small to Medium Accounting Firms. Journal of the Australasian Tax Teachers Association 13(1): 152-186.

Nathania, E. S. \& Davianti, A. 2018. An Accounting Perspective of Tax Amnesty in Indonesia. Journal of Accounting Auditing and Business 1(1): 1-18.

Papageorgiou, E. \& Callaghan, C.W. 2020. Accountancy learning skills and student performance in accounting education: evidence from the South African context. Accounting Education 29(2): 205-228.

Rebele, J.E. \& St. Pierre, E.K. 2019. A commentary on learning objectives for accounting education programs: The importance of soft skills and technical knowledge. Journal of Accounting Education 48: 71-79.

Runtuwarow, R. \& Elim, I. 2016. Analisis Penerapan Akuntansi Pajak Penghasilan Pasal 21 atas Gaji Pegawai Negeri Sipil pada Dinas Perkebunan Provinsi Sulawesi Utara. Jurnal EMBA: Jurnal Riset Ekonomi, Manajemen, Bisnis dan Akuntansi 4(1):10-20.

Wafroturrohmah, \& Suyatmini. 2013. Penggunaan Metode Problem-Based Learning untuk Meningkatkan Kemampuan Belajar Mandiri Mahasiswa Jurusan Pendidikan Akuntansi pada Mata Kuliah Akuntansi Perpajakan. Jurnal Pendidikan Ilmu Sosial 23(1): 32-41. 